\title{
Plasma and intracellular (platelet) zinc levels in chronic renal failure (CRF) patients under different treatment modalities
}

\author{
Khalil, O.A.; Mostafa, E.; Zanaty M.A.F and *Omar, H.M.
}

Internal Medicine and *Clinical Pathology Departments, Faculty of Medicine, Zagazig University

\begin{abstract}
The causes and degree of Linc $(\mathrm{Zn})$ deficiency in uracmia are still controversal. The effect of different treatment modalities are still unsetteled. Plasma $\mathrm{Zn}$ represent only a small part of the total body $\mathrm{Zn}$ (about $0.5 \%$ ). Thus determination of intracellular $\mathrm{Zn}$ in the peripheral biood cells might be more reliable. The present study was designed to assess the actual $\mathrm{Zn}$ status in uraemia and to find whether the treatment modalitics of CRF (conservalive and dialytic) could influence $\mathrm{Zn}$ status. Also to determine the effect of single dialysis session, type of dialysis and dialysate buffer on the Zn stillus.

This study included ien healthy controls and fourty CRF patients divided in three subgroups on different reatment modalitios 110 conservative treatment, 15 on intermittent perioneal dialysis (IPD) and $150 \mathrm{~m}$ haemodialysis (III))|.

Znic wals mealsured by atome absorption sepectrophotometry in plasma and platelets.

Statistically signilicant decrease of plasma $\mathrm{Zn}$ and significant increalse of platelet $/ n$ were found in CRF patients on different treatment modalitues as compared to controls $(P<0.01)$, but there wals no significant difference in this respect between the three uraemic subgroups. There was no difference as regard serum protein and albumon levels in uramic subgroups compared to controls. Moreover plasma Zn wals significinnly increased (still less than control) and platelet $Z n$ was significantly decreased $(P<0.0)$ ) after a single dialysis session in both IPD and HD subgroups, but the changes of bosh parameters (helore and alter dialysis) were insignificant in IPD paticnts compared to HID patients.
\end{abstract}

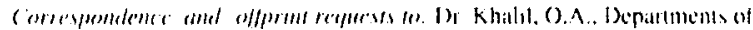

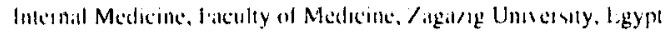

Significant negative correlation was found between platelet $\mathrm{Zn}$ and creatinine clearance in the three uraemic subgroups $(r=-0.81 P<0.01$ in conservative patients, $r=-0.72 \mathrm{P}<0.01$ in IPD and $r=-0.76 \mathrm{P}<0.01$ in HD) while no correlation could be detected between the duration of dialysis and each of platelet \& plasma $\mathrm{Zn}$ and between and plasma $\mathrm{Zn}$ and each of platelet $\mathrm{Zn}$, serum creatinine and clearance. Plasma $\mathrm{Zn}$ showed transient significant rise in HD patients

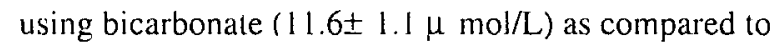
those using acetate buffer $(9.1 \pm 1.3 \mu \mathrm{mol} / \mathrm{L}), \mathrm{P}<0.01)$. We can conclude that intracellular measurements of $\mathrm{Zn}$ (platelet) is of value in diagnosis and monitoring of $\mathrm{Zn}$ status in uraemics. Different treatment modalities does not influence $\mathrm{Zn}$ haemostasis. with no superiority of particular type of dialysis in this respect. The effect of a single dialysis session and the use of bicarbonate versus acetate huffer was just a transient rise of plasma $\mathrm{Zn}$ due to hacmoconcentration and better correction of acidosis during dialysis.

\section{Introduction}

Zine $(\% n)$ is present in a large number of proteins and encymes, e.g. metallo-thionine and DNA-binding proteins. It is essential for gene expression, growth hormone activity, cellular signal transduction, neurotransmitter receptors and membrane functions [24]. It had been reported that uraemic patients have abnormal $\mathrm{Zn}$ metabolism [16]. The change in $\mathrm{Zn}$ metabolism may be responsible for certan features of uracmia |18|. These features include gonadal dysfunction [14]. hyperprolactinaemia [13] and neuropathy $|21|$. 
The causes and degree of $\mathrm{Zn}$ deficiency in uraemia are controversal, it may be due to decreased $\mathrm{Zn}$ absorption [1] due to specific $\mathrm{Zn}$ transport defect or the absence of intestinal $\mathrm{Zn}$ ligands as picolinic acid [16].

$\mathrm{Zn}$ is usually measured in plasma or serum as it is easily accessible and relatively simple to process. However, plasma values represent only a small percentage $(1-2 \%)$ of body content.

Determination of plasma $\mathrm{Zn}$ does not provide conclusive evidence of $\mathrm{Zn}$ deficiency [20]. Thus diagnosis of mild and moderate $\mathrm{Zn}$ deficiency is still an unsolved problem and increased attention should be devoted to the intracellular measurement in erythrocyte (which contain 85\%), platelet and leucocytes which represent tissue $\mathrm{Zn}$ [6]. Red blood cells (RBCs) have slow turnover, thus $\mathrm{Zn}$ content does not reflect current $\mathrm{Zn}$ status and platelet $\mathrm{Zn}$ is a more reliable index of short term changes [19].

This study was designed to assess the actual $\mathrm{Zn}$ status in uraemia and to find out whether treatment modalities of CRF (conservative and dialytic) influence $\mathrm{Zn}$ haemostasis. Also to determine the effect of single dialysis session, type of dialysis and dialysate buffer (bicarbonate and acetate) on the $\mathrm{Zn}$ status.

\section{Materials and methods}

This study was carried out in the Internal Medicine (Nephrology Unit) and the Clinical Pathology Departments, Zagazig University Hospitals.

\section{Subjects}

We included fifty subjects in this work, they were divided into:

I. Control group: It comprised ten adult healthy volunteers (six males \& four females), their ages ranged from 19-65 years with a mean of $41.3 \pm$ 11.3 years. They had normal renal functions.

II. Chronic renal failure (CRF) group: It included fourty patients divided into three subgroups according to the line of treatment:
- Conservative subgroup: Ten patients (six males \& four females) with CRF, their ages ranged from 31-63 years with a mean of $43.71 \pm$ 13.3 years. They were on conservalive treatment for five months to two years. The etiology of CRF was glomerulonephritis in four patients and chronic pyelonphritis in six patients. The mean serum creatinine was $(4.6 \pm$ $0.72 \mathrm{mg} \%$ )

- Peritoneal dialysis subgroups (IPD): It included $15 \mathrm{CRF}$ patients (nine males \& six females), their ages ranged from 16-56 years with a mean of $44.4 \pm 12.1$ years. Duration of dialysis ranged from 6-30 months with a mean of $14.5 \pm 1.5$ months ( 8 of them were dialysed for more than one ycar). IPD was performed twice weekly with thirty liters each session. None of IPD patients was previously treated by haemodialysis. The etiology of CRF was chronic pyelonephritis in ten paticnts and chronic glomerulonephritis in five patients.

- Haemodialysis subgroup (HD): It comprised 15 patients (cleven males \& four females). their ages ranged from 16-66 years with a mean of $39.5 \pm 14.2$ years. HD was performed twicc weekly, each session lasted for 4-6 hours, 8 of them used bicarbonate buffer and the other scven patients used acelate buffer. Only cuprophanc low-flux (surface area 1-1) $\mathrm{E}_{2}$ dialysers were used. The duration of dialysis ranged from 7-42 months, with a mean of $18 \pm 3.1$ months, ( 8 of them were dialysed for more than one year). The etiology of CRF was chronic pyeloncphritis in elcven patients and chronic glomerulo-nehritis in 4 patients.

All patients in this study werc selected to be free from diabetes, hepatic diseases and malignancy and werc on recommended diet for uracmics. Those receiving erythropocitin or vit D therapy were also excluded.

All cascs were in stable condition and had no advanced complications. Patient data are shown in tablc 1 .

Table 1. Clinical data of the different groups:

\begin{tabular}{|c|c|c|c|c|}
\hline & Control group & Conservative groulp & $|P|)_{g r(H i p)}$ & (II) gromip \\
\hline Age (ycars) & $41.3 \pm 11.3$ & 43.711 .3 .3 & $44.4 \pm 12.1$ & 39.5114 .2 \\
\hline $\operatorname{Sex}(M / F)$ & $6 / 4$ & $6 / 4$ & $9 / 6$ & $11 / 4$ \\
\hline Duration of dialysis (months) & - & - & $14.5+1.5$ & $18+3.1$ \\
\hline $\mathrm{Hb} \%(\mathrm{gm} \%)$ & $14\rfloor \mid .3$ & $9.5 \pm 1.01$ & 8.510 .99 & $8.92 \mathrm{J1.03}$ \\
\hline Total protein $(g / L)$ & $8.1 \pm 0.91$ & $7.7 \pm 0.72$ & $7.6 \pm 0.63$ & $7.9-10.58$ \\
\hline Serum albumin $(g / L)$ & 4.510 .44 & $3.9 \pm 0.331$ & 3.810 .40 & $4.1 \pm 0.39$ \\
\hline S. creatinine (mg\%) & 0.910 .03 & $4.6 \pm 0.72$ & $8.2 \pm 0.9$ & $6.57 \pm 0.61$ \\
\hline Creatinine clearance $(\mathrm{ml} / \mathrm{min})$ & $93-6.3$ & 11.410 .88 & $6.4 \pm 0.46$ & $8.4-10.62$ \\
\hline
\end{tabular}




\section{Methods}

All subjects in this study were submitted to the following:

A. Thorough history and clinical examination.

B. Routine investigations including:

- Urine analysis.

- Complete blood count, packed cell volume. platelet count and platelet indices using sysmex cell counter model 3000 .

- Liver function tests especially total proteins and serum albumin and screening tests for $\mathrm{HbsAg}$ and $\mathrm{HCV}$ antibodies.

- Kidney function tests: blood urea. serum creatinine and creatinine clearance by standard methods.

- Fasting and $2 \mathrm{~h}$ blood glucose

- X-ray chest and abdominal somogram.

C. Specific test: Measurement of plasma and platelet zinc. After scparation of platelet, inc contemt was measured in both plasma and platelel bs atomic absorption spectro-photonctery $|1.5|$.

\section{Principle of assay.}

The samples were centriluged 1120() y 10 min) and their supernatents were carclills aspiraled. He then added $3 \mathrm{ml}$ of undiluted nitric alcid of he lubes and the samples were healled all 1.3.5 ( in a hloch healler until only a residuc remalimed. "I his lleatment with acid was repeated twice.

After the samples were digested. we added walclly I $\mathrm{ml}$ of a $10 \mathrm{ml} / \mathrm{L}$ solution of nitric acid lo disisolice the mineral salts. Zinc content of both plateled and plasma samples was delermined by alomic absorplion spectrophotometry (Perkin-Elmer. Model 3110 ) and appropriale zinc standards.

N.B: Samples for plasma and platelet $\mathrm{Zn}$ were oblained before and after the dialysis session in patients under dialysis treatment, but once in conservatively treated patients and control subjects.

\section{Results}

A statistically significant increase in platelet count and platelet $\mathrm{Zn} \quad(\mathrm{P}<0.01)$, and statistically significant decrease in plasma $\mathrm{Zn}$ and packed cell volume $(P C V)(P<0.01)$ were found in the three uraemic subgroups (conservative. IPD \& HD) as compared to controls, while there was no significant difference in the previous parameters between the three uraemic subgroups.

Serum albumin showed no significant difference between control group and all uraemic subgroups and between each of the three uraemic subgroups as shown in table 2 .

A statisticaly significant increase in plasma $\mathrm{Zn}$ and PCV $(P<0.01)$ and significant decrease in platelet $\mathrm{Zn}(\mathrm{P}<0.0 \mathrm{l})$ in IPD and HD subgroups after single session of dialysis was found. Platelet count was significantly increased after single dialysis session only in HD patients $(\mathrm{P}<0.01)$ as shown in table 3 .

The change $(\Delta)$ in the levels of platelet and plasma $\mathrm{Zn}_{\mathrm{n}}$ after single dialysis session (the difference in the between pre and post dialysis values) were not significant in IPD patients compared to HD subgroup as shown in table 4.

Plasma $Z_{n}$ was significantly increased in HD subgroup using bicarbonate buffer as compared to those using acetate buffer $(P<0.01)$. The rise was transient after single dialysis session, while there was no significant difference in the platelet $\mathrm{Zn}$ in acetate buffered HD patients as compared 10 bicarbonate buffered HD patients as in table 5 .

A statistically significant negative correlation between platelet $\mathrm{Zn}$ and creatinine clearance was obscrved in the all uraemic subgroups $(r=-0.81$. $P<0.01$ in conservative patients. $r=-0.72 . P<0.01$ in IPD and $r=-0.76, P<0.01$ in $\mathrm{HD}$ patients). No significant correlation could be detected between plasma $\mathrm{Zn}$ and each of platelets $\mathrm{Zn}$ and creatinine clcarance in the three uraemic subgroups similarly between duration of dialysis and each of platelet and plasma $\mathrm{Zn}$ in dialytic subgroups as shown in table 6

Tuble 2. Comparison of the mean valuts $1 S 1$ ) of platclel counl, plasma \& platlet inc packed cell volume (PCV) and serum albumin in different groups

\begin{tabular}{|c|c|c|c|c|c|c|}
\hline & (omtrol groul) & Comsenvarive group & $\mid P D$ & $H D$ & $F$ & $P$ \\
\hline Platelet counl $\left(\times 10^{4}\right)$ & $243.1+112.2$ & $\begin{array}{l}340.3+176.2 \\
a\end{array}$ & $\begin{array}{l}356.1 \pm 180.1 \\
\text { a }\end{array}$ & $\begin{array}{l}372.1 \pm 204.1 \\
a\end{array}$ & 7.693 & $<0.01$ \\
\hline Plasmal $/ \mathrm{n}\left(\mathrm{mol}_{\mathrm{mol}} / \mathrm{L}\right)$ & $14.1 \pm 1.6$ & $9.62 \pm 1.3$ & $\begin{array}{l}9.9311 .4 \\
a\end{array}$ & $\begin{array}{l}10.06 \pm 2.1 \\
\mathrm{a}\end{array}$ & 14.332 & $<0.01$ \\
\hline Pletelel Zn(ninol/10" cells) & 190.8194 .3 & $329.7 \pm 215.4$ & $329.9-1218.9$ & $309-206.2$ & 9.82 & $<0.01$ \\
\hline $\operatorname{PCV}(\%)$ & $43.9-44.2$ & $\begin{array}{l}31.6+4.3 \\
a\end{array}$ & $31.5+4.2$ & $30.2+4.2$ & 18.37 & $<0.01$ \\
\hline Secum albumin $(g / 1)$, & $4.5 \pm 0.44$ & $3.9 \pm 0.331$ & $3.8 \pm 0.401$ & $4.1 \pm 039$ & 0.071 & NS \\
\hline
\end{tabular}

$a=$ Significant in comparison to control group. $b=$ Significant in comparison to conservative group.

$\mathrm{c}=$ Significant in comparison to IPD group. 
Table 3. Comparison of the mean values $\triangle S D$ of platelet count and zinc, plasma zinc and PCV in IPD and HD group before and after one dialysis session

\begin{tabular}{|c|c|c|c|c|c|c|c|c|}
\hline & \multicolumn{4}{|c|}{$I P D$} & \multicolumn{4}{|c|}{$H D$} \\
\hline & Before & after & $T$ & $p$ & before & after & $\mathrm{t}$ & $\mathrm{p}$ \\
\hline Platelet count $\left(\times 10^{9}\right)$ & $356.1 \pm 180.1$ & $361.9+193$ & 1.145 & NS & $372.1 \pm 204.1$ & 411.21197 .4 & 6.921 & $<0.01$ \\
\hline Plasma $\mathrm{Zn}($ ( mol/L) & $9.43-1.4$ & 10.911 .2 & 9.22 & $<0.01$ & $1,0.06 \pm 2.1$ & $11.02 \dashv 2.4$ & 6.934 & $<0.01$ \\
\hline Platelet $\mathrm{Zn}\left(\mathrm{nmol} / 10^{9}\right.$ cells $)$ & $329.9-1218.9$ & $299.5 \pm 211.9$ & 10.82 & $<0.01$ & $309-206.2$ & $282.5 \pm 200.3$ & 7.63 & $<0.01$ \\
\hline $\operatorname{PCV}(\%)$ & $31.5+4.2$ & $34.2+3.4$ & 5.056 & $<0.01$ & $30.2-44.3$ & $36.3-13.2$ & 5.99 & $<0.01$ \\
\hline
\end{tabular}

Table 4. Mean values ISD of changes ( $\iota$ ) in the levels of platelet and plasma zinc in IPD and HD groups after single dialysis session

\begin{tabular}{lllll}
\hline & IPD & $H D$ & $t$ & $P$ \\
\hline Lof plasma zinc (lmol/L) & $0.97 \pm 0.2$ & $0.96 \pm 0.3$ & 0.451 & NS \\
Lof platelel zinc (nmol/10 cells)) & $349+7.4$ & $265.5 \pm 5.3$ & 1.763 & NS \\
\hline
\end{tabular}

Table 5. Comparison of the mean value $\mathrm{SD}$ of plasma and platelet $\operatorname{sinc}$ in HD subgroup using acetate versus bicarbonate burfer

\begin{tabular}{lllll}
\hline & HD using acetate $(n=8)$ & HD using bicarbontate $(n=7)$ & 1 & $P$ \\
\hline & & 11.611 .1 & 4.328 & $<0.01$ \\
Plasma zinc $(\mu \mathrm{mol} / \mathrm{L})$ & $9.1+11.3$ & $307 \pm 111.2$ & 2.093 & NS \\
\hline
\end{tabular}

Table 6. Correlation coefficient between platelet and plasma zinc and the different parameters in the thrce uracmic subgroups

\begin{tabular}{|c|c|c|c|c|c|c|}
\hline \multirow[t]{2}{*}{ Variable } & \multicolumn{2}{|c|}{ Conservative group } & \multicolumn{2}{|l|}{$I P D$} & \multicolumn{2}{|l|}{$H D$} \\
\hline & $r$ & $p$ & $r$ & $\mathrm{p}$ & $r$ & $\mathrm{P}$ \\
\hline Plasma $\mathrm{Zn}$ versus platelet $\mathrm{Zn}$ & -0.36 & NS & -0.33 & NS & -0.27 & NS \\
\hline Plasma $\mathrm{Zn}$ versus platelet count & -0.24 & NS & -0.23 & NS & -0.31 & NS \\
\hline Plasma $Z n$ versus creatinine clearance & 0.33 & NS & 0.34 & NS & 0.28 & NS \\
\hline Plasma $\mathrm{Zn}$ versus duration of dialysis & - & - & 0.31 & NS & 0.18 & NS \\
\hline Platelet $\mathrm{Zn}$ versus platiet count & -0.22 & NS & -0.17 & NS & -0.19 & NS \\
\hline Platelet $Z n$ versus creatinine clearance & -0.81 & $<0.01$ & -0.72 & $<0.01$ & -0.76 & $<0.01$ \\
\hline Platelet $\mathrm{Zn}$ versus duration of dialysis & - & & 0.14 & N.S. & 0.26 & N.S \\
\hline
\end{tabular}

\section{Discussion}

$\mathrm{Zn}$ is an essential component of a large number of metalloenzymes and is important for normal metabolism in man [6]. It had been reported that patients with chronic renal failure have an abnormal zinc metabolism [16]. These changes in $\mathrm{Zn}$ metabolism may account for certain feature of uraemia [18].

In the present study serum albumin and protein did not show any difference in the three uraemic subgroups as compared to controls, which exclude the effect of hypoalbuminaemia in $\mathrm{Zn}$ haemostosis. Plasma $\mathrm{Zn}$ levels were significantly lower is uraemic patients under different treatment modalitics (conservative, IPD and HD) compared to control, indicating deficiency of circulating $\mathrm{Zn}$ in uracmics. Similar results were obtained by others $|11,20,25|$. Paniagua et al. [16] attributed low circulating $\mathrm{Zn}$ level in uracmia to low $\mathrm{Zn}$ intake, a specific $\mathrm{Zn}$ transport defect or absence of specific $\mathrm{Zn}$ ligands. Other studies suggested impaired absorption [8]. Several factors are thought to bc involved in malabsorption as chronic cnteritides and excessive losses (five times higher than the uptake of $\mathrm{Zn}$ may occur) [2]. Impaired tubular reabsorpation caused by the uraemic milieu was also suspected [23]. 
The low plasma $\mathrm{Zn}$ levels in the three uraemic subgroups in this study denote failure of any treatment modality to correct circulating $\mathrm{Zn}$ level. The absence of correlation between plasma zinc and duration of dialysis in dialytic subgroups and non significant difference of plasma $\mathrm{Zn}$ between the uraemic subgroups and each other indicate failure of dialytic therapy (IPD \& HD) to correct plasma $\mathrm{Zn}$. This is in agreement with the results obtained by Kaminska - Galwa et al. [7] who found low plasma $\mathrm{Zn}$ level in uraemics, which was similar in both short and long term dialysis groups.

It seems impossible to diagnose $\mathrm{Zn}$ deficiency by plasma level only, as it accounts for 1-2\% of the entire pool, the largest amount of $\mathrm{Zn}$ is present intracellularly. Erythrocytes contain (85\%) [9], but it has slow turn over and does not reflect current $\mathrm{Zn}$ status, while platelets have an average life span 7-10 days and its $\mathrm{Zn}$ content could be a more reliable index of short term changes in $\mathrm{Zn}$ status $\{19,20]$.

In this study platclet $\mathrm{Zn}$ was significantly higher in the threc uraemic subgroups compared to controls. This result was supported by previous results obtained by Schmilt $|20|$ who found that $\mathrm{Zn}$ is elevated in crythrocytcs and platclets of uremics. These findings may be explained by abnormal shift of $\mathrm{Zn}$ from plasma to the intraccllular compartment |22].

These results point to change in distribution of $\mathrm{Zn}$ in uracmics resulting in decreased plasma $\mathrm{Zn}$ and increased intraccllular sinc (platelet). So in uraemic patients we can nol depend on plasma zinc level to diagnose $\mathrm{Zn}$ deficiency. This concept could be illustrated by a study dione by Chen \& Yang [3] who found that platclet $\mathrm{Zn}$ was similar in uremics and controls but in the same study plasma $\mathrm{Zn}$ was markedly low indicaling severe deficiency.

In view of the above results intracellular $\mathrm{Zn}$ is a morc reliable index for diagnosis and monitoring of $\mathrm{Zn}$ slatus than plasma Zn.

Platclet $\mathrm{Zn}$ was negatively correlated with creatinine clearance in our uracmic subgroups but plasma $\mathrm{Zn}$ was not, indicating the close relation between tissue Zn (plateles) and degrec of renal impairment. However there was no correlation between plasma and platelet $\mathrm{Zn}$ in the different studied subgroups. These results were supported by those of lotova et al. |6|. Hinks et al. |5| recommended measurement of erythrocyle $\mathrm{Zn}$ content in order to determine the long term $\mathrm{Zn}$ status. For assessment of acute changes, Icukocyles might be more suitable not only because of Ihcir shorter life span, but because they are nucleated, metabolically morc active and thus more representive of other body compartments $[4,17]$.

After a single dialysis session we found that plasma Zn was significantly higher in both dialytic subgroups compared to their values before the session, however, levels were still significantly lower than controls. This clcvation was in agrccment with the result obtained by Lin et al. [11]. It may be due to haemoconcentration as packed cell volume (PCV) was also significantly higher after the dialysis session although it was still lower than that of controls [6]. Platelet $\mathrm{Zn}$ was significantly decreased after the dialysis session compared to their values before dialysis in the two dialytic subgroups in our study. Similar results were obtained by Iotova et al. [6] and this transient change may be attributed to changes that occur during dialysis as redistribution of $\mathrm{Zn}$ from platelet to plasma or to the increased platelet count as we found in our patients during hemodialysis secondary to the effect of anticoagulants. We also found that there was no significant difference between the change in $\mathrm{Zn}$ status (plasma \& platelet) in patients under HD in comparison to those under peritonial dialysis, indicating no superiority of either type of dialysis for correction of $\mathrm{Zn}$ status in CRF. Meanwhile plasma but not platelet $\mathrm{Zn}$ was transiently and significantly increased in patients on bicarbonate haemodialysis compared to those using acetate buffer. This finding was confirmed by Iotova et al. [6], denoting a more beneficial effect of bicarbonate buffer for correction of acidosis with subsequent improvement of $\mathrm{Zn}$ absorption.

We can conclude that intracellular measurment of $\mathrm{Zn}$ (platelet) is of value for diagnosis and monitoring of $\mathrm{Zn}$ deficiency states in uraemics. Furthermore treatment modalities of CRF do not influence $\mathrm{Zn}$ haemeostasis, with no superiority for a particular type of dialysis in this respect. A single dialysis session and the use of bicarbonate buffer caused transient elevation of plasma zinc, due to hemoconcentration and better correction of acidosis respectively that occur during dialysis.

\section{References}

1. Abu Ilandan. D.K., Mahajan, S.K., Migdol, S.D., Prasad, A.S. and McDonald, F.: "Zinc tolerance test in uremia, Effect of ferous sulfate and aluminum hydroxide". Ann. Int. Med, 1986: 04: 50-52

2. Cheek, D.B., Hay, H.J., Latanrio, L., ness, D., Ludwigsen, N. and Spargo, R.: Zinc content of red and white blood cells in aboriginal children. Aust NZ. J. Med., 1984; 14: 638-642

3. Chen, S.M. and Young, T.K.: "Reduced gluthathione. supero-xide dismutase content and malondialdhyde formation in plateless from uraemic patients, relation to plasma and platelet zinc. J. Formos. Med. Assoc., 1992; 91 (2): 180-4.

4. Dycker, T. and Wester, P.O.: Skeletal muscle magnesium and potassium determinations: correlation with lymphocyte contents of magnesium and potassium. J. Am. Coll. Nutr.. $1985 ; 4: 619-625$.

5. Hinks, L.J., Clayto, B.E. and Lloyd, R.S.: Zinc and copper concentrations in leucocytes and erythrocytes in healthy adults, the effect of oral contraceptives. J. Clin. Pathol., 1993; 36: 1016-1021

6. Iolova, P., Ionova, D., Kuleva, V., Antonov, S., Tzachev, $K$. and Nochv Ch: "Zinc in plasma and pletelets in patients on 
regular hemodialysis". J. Dialysis \& Transplanation, 1997; 370-371.

7. Kaminska-Galwa, B.J., Grzeszczak. W., Jedryczko. A. and Pachelki. J.: "Influence of long term hemodialysis on serum trace element concentration in patients with end stage renal failure". Prazegl-Lek, 1994; 51 (1): 9-14 (Abstracl).

8. Kouw, P.M., Kounings, C.H., De Vries, P.J. and Meulen, J.: Zinc absorption in hemodialyis patients. Amn. Clin. Biochem.. 1989: $26: 455-456$

9. Kruse-Jarres, J.D.: Crenzen derzeitigen Kenntnise uber die Bledevtuny and Autgaben der Sperentelemente in menschlichen organismus. Vita Min. Spur. 1987; 2: 6-12.

10. Kruse-Jarres, J.D.: Die Verteilung der Spurenelemente im menschlichen Organisms. VitaMinSpur., 1990: 5: 6-17.

11. Lin. T.H., Chen, J.G., Liaw, J.M. and Juang. J.G.: "Trace elements and lipid peroxidation in uraemic patients on hemodialysis", 1996.

12. Mahajan, S., Bowersox, E., Rye. B., Abu Hamdan. D., Prasad, A.. McDonald, F. and Biersack, K.: "Factors underlying abnormal zinc metabolism in uraemia". Kid. Inter., 1989; Vol.. 36 Suppl. 27 pp. 269-273.

13. Mahajan, S.K., Hamburger. R.J.. Flamenbaum, W., Prasad, A.S. and McDonald, F.: "Effect of inc supplementation on hyperprolactinemia in uraemic men". Lancet, 1985; I: 750-75I.

14. Mahajan, S.K., Prasad, A.S. and McDonald. F.D.: 'Sexual dysfunction in uraemic male: improvement following oral sinc supplementation". Contr. Neprol., 1984: 38: 103-112.

15. Milne, D.B.; Ralston. N.V. and Wallork, J.C.: Zinc content of cellular components of blood. Clin. Chem.. 1985; 31 (I): $65-$ 69.

16. Paniagua, R.; Claure, R.: Amato, D.: Flores, E. and Exairc. E.: Effect of oral administration of inc and diiodohydroxyquinolein on plasma rine level of uracmic patients. Nephron, 1995; 69: 147-150

17. Patrick, J. and Dervish. C.: Leucocyle rinc in the assessment of zinc status. Crit. Rel. Clin. Lab. Sci., 1984: 2: 95-114.

18. Prasad. A.S.: Rabbani, P.; Abbasi. A.: Bowersox, E. and Fox. M.: "Experimental inc deliciency in human". Ann. Int. Med. 1976: 89: 483-490

19. Ru/. M.: Cal an. K. and Belleger. W.: "Erythrocyte, eryıhroc)te membranc. neutrophil and platelet as a biopsy material for the assesment of sinc status in human". Am. J. Nutr. 1992: $68: 51.5-527$

20. Shmill: Copper and sinc determination in plasma and corpuncular components of peripheral blood of patients with presmmal and terminal renal failure. J. Trace elements Med. Biol. 1997: Vol. 11. pp. 210-214

21. Sprenger. K.. Bundachu. D.. Lewis, K. Spohn. B.. Schmil, Z.J. and Iran/ II.: Improvement of sine neuropathy and hypogensia by dialyate rinc supplementations, A double blind study". Kidney InI.. 1983: |Suppl 241: 315-318.

22. Sudesh, K.M. and Prasad, A.S.: Zinc melabolism in uraemia. J. Lab. Clin. Med.. 1979: 94:693

23. Torrubia. J.O. and Garay. R.: Evidence of a major route for sinc uptake in human red blood celis. J. Cell Physiol. 1989 138: $316-22$

24. Vahter, M., Lut/. E., Lind, B., Herin, P., Bui, T. and Krakan, I.: Concentrations of copper, inc and sclenium in brain and kidney of second trimaster fetuses and infnats". J. Trace Elements Med Biol. 1997; Vol. I11. pp.215-222

25. Van-Renterghem. D.. Cornelis, R., Mees $L$ and Vanholder. R.: The elfect of adding br or $\mathrm{Zn}$ supplements to the dialysate on the concentration of $\mathrm{Br}$ and $\mathrm{Zn}$ in the blood of hemodialysed patients". J. Trace. Elem-Electro-lytesleallh-Dis. 1992: 6(2): 105-109. 